\title{
NEOPLASTIC TRANSFORMATION OF MOUSE C3H 10T1/2 AND SYRIAN HAMSTER EMBRYO CELLS BY HEAVY IONS
}

\author{
L. Hieber, ${ }^{*}$ G. Ponsel, ${ }^{* *}$ K. Trutschler, ${ }^{*}$ S. Fenn ${ }^{*}$ and \\ A. M. Kellerer* \\ "Institut für Medizinische Strahlenkunde der Universität Würzburg, \\ Versbacher Strasse 5, D-8700 Würzburg, F.R.G. \\ **Institut für Biotechnologie der Universität Würzburg, Röntgenring 11, \\ D-8700 Würzburg, F.R.G.
}

\begin{abstract}
C3H 10T1/2 mouse-embryo fibroblasts were used for transformation experiments to study the effectiveness of various heavy ions with energies up to $20 \mathrm{MeV} / \mathrm{u}$ and LmT values from 170 to $16.000 \mathrm{keV} / \mathrm{mm}$. The transformation frequency per unit absorbed dose decreased with increasing ionization density; at the highest values of IIIT we found a decrease even of the transformation efficiency per untt fluence. Urenium lons at energies of 5,9 , and $16.3 \mathrm{MeV} / \mathrm{u}$ did not induce any transformation.
\end{abstract}

In additional studies primary Syrian hamster embryo cells (SHE) were exposed to heavy ions in order to characterize cytological and molecular changes which may be correlated with neoplastic transformation. Growth behaviour, chromosonal status, tumorigentcity in nude mice, and expression of oncogenes of transformed cell lines were examined.

\section{INTRODUCTION}

Radiation carcinogenesis is seen as the dominant risk of lonizing radiations at low doses. In view of a possible, more generel introduction of heavy ion radiotherapy and also in view of any future manned space activities, it is of especial interest to assess the cancer risk due to heavy ion exposure. The lack of epidemiological data and the paucity of relevant antmal studies make it necessary to base risk considerations also on transformation studies in vitro.

The transformation efficiencles of different lonizing radiations have been studied in different cell systens, i.e. C3H 10T1/2, Balb/c 313 and Syrian hamster embryo cells (SHE). Transformation studies with $\gamma$ - and x-rays have been performed by Borek and Fall /1/, Terzaghi and Iittle $12 /$, Miller et al. $13 /$. Han et al. $/ 4 /$. Miller and $\mathrm{Hall} / 5 /$, and others. Results for neutrons have been given by Borek et al. $/ 6 /$, Barendsen and Gatser $/ 7 /$, han and wind $/ 8 /$, Hill et al. $19 /$, and Balcer-Kubiczek et al. $/ 10 \%$. There have been also a number of transfor mation studies with densely ionizing $\alpha$-particles by Robertson et al. $111 /$, Iloyd et al. 112/, Hall and Hei /13/, and Hleber et al. /14/. Data for heavy lons of intermedtate LET results were reported by lang et al. /15/. The afm of the present study with C3H 10T1/2 mouse embryo fibroblasts was to extend the informations about the inactivation and transformation effectiveness for different heavg lons in the LET range from $170 \mathrm{keV} / \mathrm{hm}$ up to $16,000 \mathrm{keV} / \mathrm{\mu m}$.

Beyond the direct interest in the transformation effectiveness of different lonizing radiations, it is desirable to obtain information about the mechanisms underlying the transformation process(es) induced by iontzing radiation. Therefore, it is important to investigate parameters which may correlate with the transformed phenotype of a cell. The growth behaviour, i.e. plating efficiency, population doubling time, and growth in semi-solid medium, the induction of tumors in athymic nude mice, and the chromosomal status of Syrian hamster embryo (SHF) cell lines transformed by carbon Ions were investigated. In addition, recent results are given on the expression of the E-ras-oncogene in cells transformed after exposure to densely ionlzing heavy ions (carbon lons) and in the related tumor-cell ines.

\section{MEIHODOLOGY}

\section{Cell culture and irradiation procedures}

The transformation study was performed with C3H 10T1/2 mouse-embryo fibroblasts developed by Reznikoff et al. $/ 16 /$. The cells were maintalned in Eagle's basal medium (Gibco) supplemented with 10 per cent heat-inactivated fetal bovine serum (Boehringer) $50 \mathrm{w} / \mathrm{ml}$ penicilitin, and 
$50 \mu \mathrm{g} / \mathrm{ml}$ streptonjcln (BRL). Cells of passage 12 were cultured in $75 \mathrm{~cm}^{2}$ flasks (Greiner) and incubated in a humldified gas atmosphere ( 95 per cent air and 5 per cent $\mathrm{CO}_{2}$ ) at $37^{\circ} \mathrm{C}$. The plating efflciency of control cultures was between 20 and 30 per cent. Twenty-four hours before irradiation the cells were plated in petri dishes of $3.5 \mathrm{~cm}$ diameter at a final density (at the time of irradiation) of $10^{4} / \mathrm{cm}^{2}$ in order to achieve exponential growing cell populations during exposure.

Irradiations with dfferent heavy lons were performed at the linear accelerator UNIIAC of the Gesellschaft fir Schwerlonenforschung (GSI) in Darmstadt. Just before the irradiation the petri dishes were transferred into a medium-filled teflon magazine and were irradiated vertically in an exposure facility with automatic sample changer constructed by the GSI 117/. The heavy ion beams were defocussed and the samples were wobbled to schieve homogenous irradiations. An integrated part of the exposure facility is a secondary electron emission chamber that monitors the Ion beam current. This monitor was calibrated by comparison with the particle fluence determined from track counts on etched glass or on CR39-samples.

\section{Survival and transformation assay}

Immediately after irradiation the cells were trypsinized, and held on ice till plating. If more than about 105 cells were necessary for the transformation and survival assay at a specified dose, two or more dishes were irradtated successively and the samples were pooled.

For the survival assay the numbers of plated cells were suitably chosen to attain about 80 viable cells per $25 \mathrm{~cm}^{2}$ flask. The flasks were incubated for 10 days, then fixed and stained with 10 per cent Giemsa, colonies with more than 50 cells were counted as survivors.

For the transformation assay the cells were plated in $25 \mathrm{~cm}^{2}$ flasks with about 300 viable cells per flask. The cells were incubated for 6 weeks with a weekly medium change. After fixation and staining the numbers of transformed foci were determined; only foci of type 2 and 3. as described by Reznikoff et al. $/ 16 /$, were scored as transformants. The transformation frequency per surviving cell were determined as described earlier $/ 14 /$.

Transformation of Syrian hamster embryo cells

Primary Syrian hanster embryo cells isolated from 12 days old embryos were frozen in Iiquid nitrogen as stock cultures. For the experiments cells were thawed and maintained in IBR medium (GIbco) supplemented with 20 per cent fetal bovine serum and antibiotics. The cells were incubated in a humidified gas atmosphere of 90 per cent air and 10 per cent $\mathrm{CO}_{2}$ at $37^{\circ} \mathrm{C}$. Cells of passage 2 to 3 were used for the experiments. The irradiation procedure for SHE cells was the same as described above. After irradtation the cells were trypsinized and $5 \times 105$ cells were plated in $75 \mathrm{~cm}^{2}$ flasks. Before reaching confluency the cells were subcultured repeatedily until the primary cells aged and imnortal or transformed cells overgrew the aged, dying cells.

\section{Tumorigenicity in athymic nude mice}

The transformed cell lines were grown in $75 \mathrm{~cm}^{2}$ flasks, trypsinized and resuspended in glucose-containing phoshate buffered saline ( 107 cells per ml). $2 \times 10^{6}$ cells were subcutanously injected into athymic nude Balb/C mice. The enimals wero weekly controlled for tumor induction. Tumors growing under the skin of mice were isolated from kflled aninals one week after appearance. The tumors were minced, transferred to petri dishes, fed with medium containins 10 per cent fetal bovine serum, and incubated at $37^{\circ} \mathrm{C}$. One day later the remaining fragments of the tumor were removed during a medium change. Cells attached to the dishes were grown for a few days and were then frozen in liquid nitrogen, to serve as tumor-cell lines for further experiments.

\section{Growth behaviour assays}

Plating efficiency. The plating efficlency of the transformed cell lines was determined by the usual colony formation assay, as described above for the survival assay.

Population doubling time. The population doubling time was estimated from the exponential part of the growth curves. $5 \times 10^{4}$ cells of each cell line were plated in $6 \mathrm{~cm}$ dishes and every 24 hours one sample was trypsinized and the cell number was counted using a coulter Counter. 
Anchorage independent srowth. The competence for anchorage Independent growth was tested in semi-solid medium. A solution of 1.2 per cent Bactoagar (Dffco) and 0.4 per cent Bactopeptone (Difco) mixed with an equal volume of double-concentrated medium was used as base lajer and was pipetted Into $6 \mathrm{~cm}$ petrl dishes and cooled at $4{ }^{\circ} \mathrm{C}$. Between $10^{4}$ and $10^{6}$ cells suspended in normal medium mixed with the double volume of the bese-layer solution were plated on the base lajer. The cells were incubated for four weeles; after half the Incubation time the cells were fed with fresh medium. One day before scoring colontes, 1 ml of a 2-(p-1odophenyl)-3-(p-nitrophenjl)-5-phenyltetrazolium-chloride solution (1 mg/ml, Aldrich chemle) was added to the cultures accordins to the procedure of Schaeffer and Frlend /18/. The plating efficiency in semi-solid medium was estimated from the number of colontes divided by the number of cells initially plated.

\section{Determination of chromosome numbers}

Cells were grown in $75 \mathrm{~cm}^{2}$ flasks for 24 hours, $0.05 \mu \mathrm{g} / \mathrm{ml}$ Colcentde was added for 3 hours, and mitotic cells were harvested by shaking the culture flasks. The mitotic cells were incubated in $75 \mathrm{mM}$ potassium chloride, fixed with Carmog solution, spred on mtcroscopic slides, atr dried, and stained with 10 per cent Glemsa. Chromosome number per cell wero counted from at least 50 metaphase cells.

\section{Expression of H-ras oncogene}

Total RNA of transformed and tumor-cell Ines was isolated by acid guanidinium thiocjanatephenol-chloroform extraction according to the method of Chomczynski and Sacchl /19/. If-rasexpression was determined by Northern-blotting. Equal amounts of total RNA were separated by electrophoresis on agarose gels ( 1 per cent) and were blotted onto Nylon filters (Amersham). The RNA was fixed on the filters by UV-Irradiation and baking the filters for 2 hours at $80^{\circ} \mathrm{C}$. The filters were hybridized with a 32-P-nick-translated human I-ras DNA-probe (Anersham). The relative amount of ras-mRNA was estimated from the autoradograns (Zodak XAR or $S$ $x-r a y ~ f i l m)$ of the filters by comparing with signals of hybridizations of the same filters with an $\alpha$-actin probe.

\section{RESUIIS AND DISCUSSION}

\section{Inactivation and transformation of C3H $10 \mathrm{~T} 1 / 2$ cells by heavy lons}

C3H $10 \mathrm{~T} 1 / 2$ cells were exposed to varlous heavy lons of energies between 4.6 and $18.6 \mathrm{MeV} / \mathrm{u}$, e.8. carbon, oxyzen, argon, iron, krypton, lead, and uraniun ions. Beam perameters, such as energy and Iinear energy transfer (III). are listed in table 1. Irradiations with all heavy ions led to exponential survival curves. The inactivation cross section, $\sigma$, for the different heavy lons, was dertved from the slope of the survival curves:

$$
-\ln S(\Phi)=\sigma \Phi
$$

where $S$ is the surviving fraction and $\Phi$ the particle fluence. The heavier ions with their larger IEl-values were associated with the highest inactivation cross sections up to $89 \mathrm{~m}^{2}$. These maximal inactivation cross sections for $10 \mathrm{~T} 1 / 2$ cells are similar to those found for V79 Chinese hamster cells /20/; however, the geometrical cross section of 10T1/2 cells is about twice that of 179 cells.

RABLE 1 Energy, Linear Energy Transfer (LIT), and Inactivation Cross Sections, $\sigma$, for C3H $10 \mathrm{~T} 1 / 2$ Cells of Different Heavy Ions and 241-Americium $\alpha$-Particles

\begin{tabular}{lccc}
\hline Particle & $\begin{array}{c}\text { Energy } \\
(\mathrm{MeV} / \mathrm{u})\end{array}$ & $\begin{array}{c}\text { LET } \\
(\mathrm{keV} / \mu \mathrm{m})\end{array}$ & $\begin{array}{c}\sigma \\
\left(\mu \mathrm{m}^{2}\right)\end{array}$ \\
\hline $\begin{array}{l}\text { a-particle } \\
\text { Carbon }\end{array}$ & 0.67 & 147 & 40 \\
Oxygen & 5.5 & 220 & 57 \\
Argon & 8.0 & 170 & 58 \\
& 9.0 & 275 & 40 \\
Iron & 4.6 & 1800 & 51 \\
Kryption & 6.5 & 1500 & 39 \\
Iead & 14.0 & 1050 & 32 \\
Uraviun & 17.3 & 1500 & 52 \\
& 8.5 & 4300 & 65 \\
& 16.7 & 3200 & 67 \\
& 7.8 & 13900 & 89 \\
& 6.3 & 15700 & 83 \\
& 9.0 & 15300 & 77 \\
& 16.0 & 12800 & 74 \\
\hline
\end{tabular}


The increase of the cross section is less than proportional to LET and, accordingly, the relative blological effectiveness for inactivation decreases with increasing LeT of the heavy lons, as shown in floure 1. At about 900 to $1000 \mathrm{keV} / \mathrm{mm}$ the RBE vs. $\gamma$-rajs becomes smalier than unity: it decreases to about 0.1 for urantum ions with LWT values in excess of $10,000 \mathrm{keV} / \mathrm{mm}$.

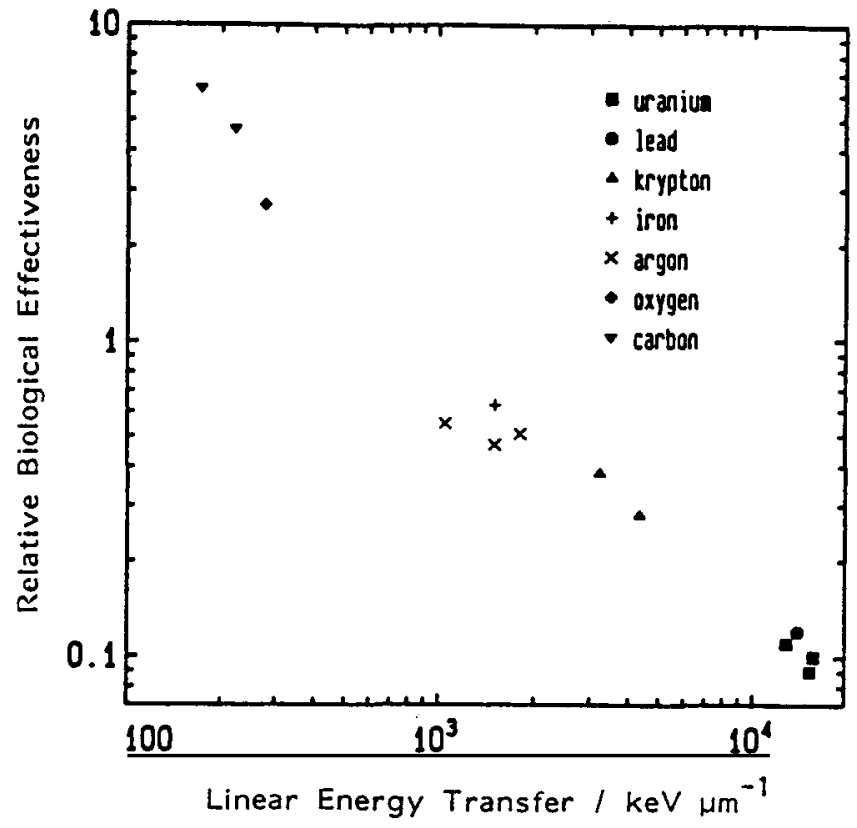

Fig. 1. The relative biological effectiveness of different heavy ions for the inactivation of $\mathrm{C} 3 \mathrm{H}$ 10T1/2 cells versus the linear energy transfer (LET). The data for heavy lons were compared with that of $\gamma$-rays.

Transformation frequencies per surviving cells for different heavy ions at various fluences, $\Phi$, are listed in table 2 . The data are based on single experiments only, and they are. therefore, subject to substantial statistical uncertaintles. However, there is a consistent decrease of the transformation frequencies with increasing mass of the ions at sindiar velocities. Transformation efficiencies appear to increase with increasing energy, i.e. decreasing LET, as shown for argon and kypton 10ns. The LET dependencies are in substantial agreement with the results of Yang et al. /15/ for lons with Lim values in excess of about $200 \mathrm{keV} / \mathrm{hm}$. The data support the general statement in ICRU $40 / 21 /$ that the efficiency of densely Ionizing radiations decreases at IET in excess of a few hundred keV/fom.

TABLE? Transformation Frequencles per Surviving Cell Exposed to Heavy Ions at Various Fluences, $\phi$.

\begin{tabular}{|c|c|c|c|c|c|c|c|c|c|c|}
\hline Ion & $\begin{array}{l}\text { Energy } \\
(\mathrm{MeV} / \mathrm{u})\end{array}$ & $\begin{array}{l}\mathrm{LET} \\
(\mathrm{keV} / \mathrm{mm})\end{array}$ & $2.5 \times 105$ & $\begin{array}{c}\text { Transfor } \\
5 \times 105\end{array}$ & $\operatorname{mants}_{1 \times 10^{6}}$ & $\begin{array}{l}10^{4} \text { surv } \\
1.5 \times 10^{6}\end{array}$ & $\begin{array}{l}\text { Ivors at } \\
2 \times 10^{6}\end{array}$ & $\begin{array}{r}\text { fluences } \\
3 \times 10^{6}\end{array}$ & $\operatorname{lcm}_{4 \times 10^{6}}$ & $6 \times 10^{6}$ \\
\hline $\begin{array}{l}\mathrm{C} \\
0 \\
\mathrm{Ar} \\
\mathrm{Fe} \\
\mathrm{Kr} \\
\mathrm{Pb} \\
\mathrm{U}\end{array}$ & $\begin{array}{r}8.0 \\
5.5 \\
9.0 \\
18.6 \\
4.6 \\
17.3 \\
16.7 \\
8.5 \\
7.8 \\
16.3 \\
9.0 \\
6.3\end{array}$ & $\begin{array}{r}170 \\
220 \\
275 \\
780 \\
1800 \\
1500 \\
3200 \\
4300 \\
13900 \\
12800 \\
15300 \\
15700\end{array}$ & $\begin{array}{c}1.1 \pm 0.8 \\
<0.6\end{array}$ & $\begin{array}{l}0.7 \pm 0.7 \\
0.7 \pm 0.7\end{array}$ & $\begin{array}{c}<0.5 \\
<0.5 \\
1.5 \pm 0.9 \\
1.3 \pm 0.9\end{array}$ & $\begin{array}{c}1.3 \pm 1.3 \\
<0.4 \\
2.2 \pm 1.1 \\
5.0 \pm 3.5 \\
\\
1.7 \pm 1.2 \\
0.8 \pm 0.8 \\
<0.5 \\
<0.9 \\
<0.6\end{array}$ & $\begin{array}{c}<0.6 \\
1.5 \pm 0.9 \\
2.7 \pm 1.2 \\
1.4 \pm 1.0\end{array}$ & $\begin{array}{c}2.3 \pm 1.4 \\
0.6 \pm 0.6 \\
<0.4 \\
<0.4 \\
<0.5\end{array}$ & $\begin{array}{l}1.3 \pm 1.3 \\
2.3 \pm 1.2 \\
1.1 \pm 0.8 \\
2.4 \pm 1.1\end{array}$ & $\begin{array}{l}<0.4 \\
<0.5 \\
<0.4 \\
<0.4\end{array}$ \\
\hline
\end{tabular}




\section{Tumorigenicity of SHE cells transformed by carbon ions}

Syrian hamster embryo cells were exposed to the fluences $5 \times 105 / \mathrm{cm}^{2}, 2 \times 106 / \mathrm{cm}^{2}$, and $4 \times 106 / \mathrm{cm}^{2}$ of $8 \mathrm{MeV} / \mathrm{u}$ carbon Ions; the result Ing absorbed doses were $0.14,0.56$, and $1.12 \mathrm{~Gy}$. At each dose we succeeded to isolate two independent transformed cell ines. After infection of $2 \times 10^{6}$ cells at passage 5 of the six cell lines into athymic mice each antmal developed a subcutaneous tunor, which was classified as fibrosarcoma. Thus all isolated cell innes were neoplastically transformed and tumorigenic. The time periods between injection and appearance of tumors were 5 to 6 weeles.

Growth paraneters of cells transformed by carbon lons and of the resulting tumor-cell Iines

Growth parameters, e.g. plating efficiency, population doubling time, and the cloning efficlency in semi-solid medium, have been determined for the transformed cell Itnes and for the tunor-cell lines from the nude nice and have been compared with untransformed primary SHE cells 82-9 (see table 3). The plating efficiencies of transformed and tumor cells was about 0.5 to 0.6 without feeder cells. With or without feeder layer primary cells had plating efficiencies of 0.2 and 0.3 , respectively.

TABIE 3 Growth Parameters of Cell Itres Transformed by $8 \mathrm{MeV} / \mathrm{u}$ Carbon Ions and of Tumor-Cell Iines Derived from the Transformed Cell Iines

\begin{tabular}{|c|c|c|c|c|c|c|}
\hline Cell Iine & Particle & $\begin{array}{l}\text { Dose } \\
\text { (Gy) }\end{array}$ & $\begin{array}{l}\text { Passage } \\
\text { Number }\end{array}$ & PE* & $\begin{array}{l}\mathrm{DT} * * \\
(\mathrm{hrs})\end{array}$ & $\begin{array}{c}\text { CE in soft } \\
\text { agar" }\left(x 10^{3}\right)\end{array}$ \\
\hline $82-9$ & & & 4 & $0.2-0.3$ & 20 & $<0.001$ \\
\hline $\begin{array}{l}A 40 I-1 \\
\text { T } 2802\end{array}$ & Carbon & 0.14 & $\begin{array}{l}8 \\
3\end{array}$ & $\begin{array}{l}\text { n.d. } \\
\text { n.d. }\end{array}$ & $\begin{array}{l}\text { n. d. } \\
\text { n. d. }\end{array}$ & $\begin{array}{l}0.04 \\
9.0\end{array}$ \\
\hline $\begin{array}{l}\text { A40I-2 } \\
\text { T } 2792\end{array}$ & Carbon & 0.14 & $\begin{array}{l}7 \\
4\end{array}$ & $\begin{array}{l}0.6 \\
0.31\end{array}$ & $\begin{array}{l}14.1 \\
20.4\end{array}$ & $\begin{array}{l}<0.01 \\
35.8\end{array}$ \\
\hline $\begin{array}{l}\text { A40II-1 } \\
\text { T } 2800\end{array}$ & Carbon & 0.56 & $\begin{array}{l}8 \\
3\end{array}$ & $\begin{array}{l}\text { n.d. } \\
\text { n.d. }\end{array}$ & $\begin{array}{l}\text { n. d. } \\
\text { n. d. }\end{array}$ & $\begin{array}{c}0.96 \\
10.5\end{array}$ \\
\hline $\begin{array}{l}\text { A40II-2 } \\
\text { T } 2794\end{array}$ & Carbon & 0.56 & $\begin{array}{l}7 \\
4\end{array}$ & $\begin{array}{l}0.63 \\
0.53\end{array}$ & $\begin{array}{l}13.6 \\
14.4\end{array}$ & $\begin{array}{c}<0.01 \\
4.6\end{array}$ \\
\hline $\begin{array}{l}\text { A40III-2 } \\
\text { T } 2793\end{array}$ & Carbon & 1.12 & $\begin{array}{l}7 \\
4\end{array}$ & $\begin{array}{l}0.60 \\
0.55\end{array}$ & $\begin{array}{l}13.3 \\
12.6\end{array}$ & $\begin{array}{l}0.44 \\
3.9\end{array}$ \\
\hline
\end{tabular}

*PE, plating efficiency." "DT, population doubling time derived from growth curves. \#CE in soft agar, cloning efficlency in semi-solid medium.

The population doubling time estimated from the exponential pert of growth curves was significantly shorter (about 13 hours) than that of the 82-9 cells (about 20 hours). The transformed cells, and the tumor cells have, thus, a pronounced growth advantage; they overgrow untransformed normal cells rapidly.

The cloning efficiency in semi-solid mediun of primary cells was less than $10^{-6}$. In contrast, between 1 out of 105 and 1 out of 103 cells of the transformed lines were able to grow in soft agar. The tumor-cell lines showed even higher cloning efficiencles, between roughly 0.004 and 0.04 . The tumor-cell line T2792 is a seeming exception, with its low plating efficiency of 0.31 and 1ts long doubling tine of 20.4 hours but with the highest cloning efflciency in soft agar. However, the low plating efficiency and the low growth rate may be experimental artefacts; T2792 cells had a tendency to Grow unattached and only the attached cells and clones were counted. The ability to grow unattached is in line with the high cloning efficiency in semt-solid medium. Since a part of the T2792 cells grow in suspension they were not included in the data to establish growth curves.

\section{Chromosome nunber per cell of transformed and tumor-cell Itnes}

The diploid set of chromosomes of normal Syrian hamster cells consists of 44 chromosomes (see figure 2 a). We determined the number of chromosomes per cell of 3 transformed cell iines, 3 soft agar subclones of one transformant, and one tumor-cell line (T2800) with, additionally, 3 subclones grown in semi-solid medium. 

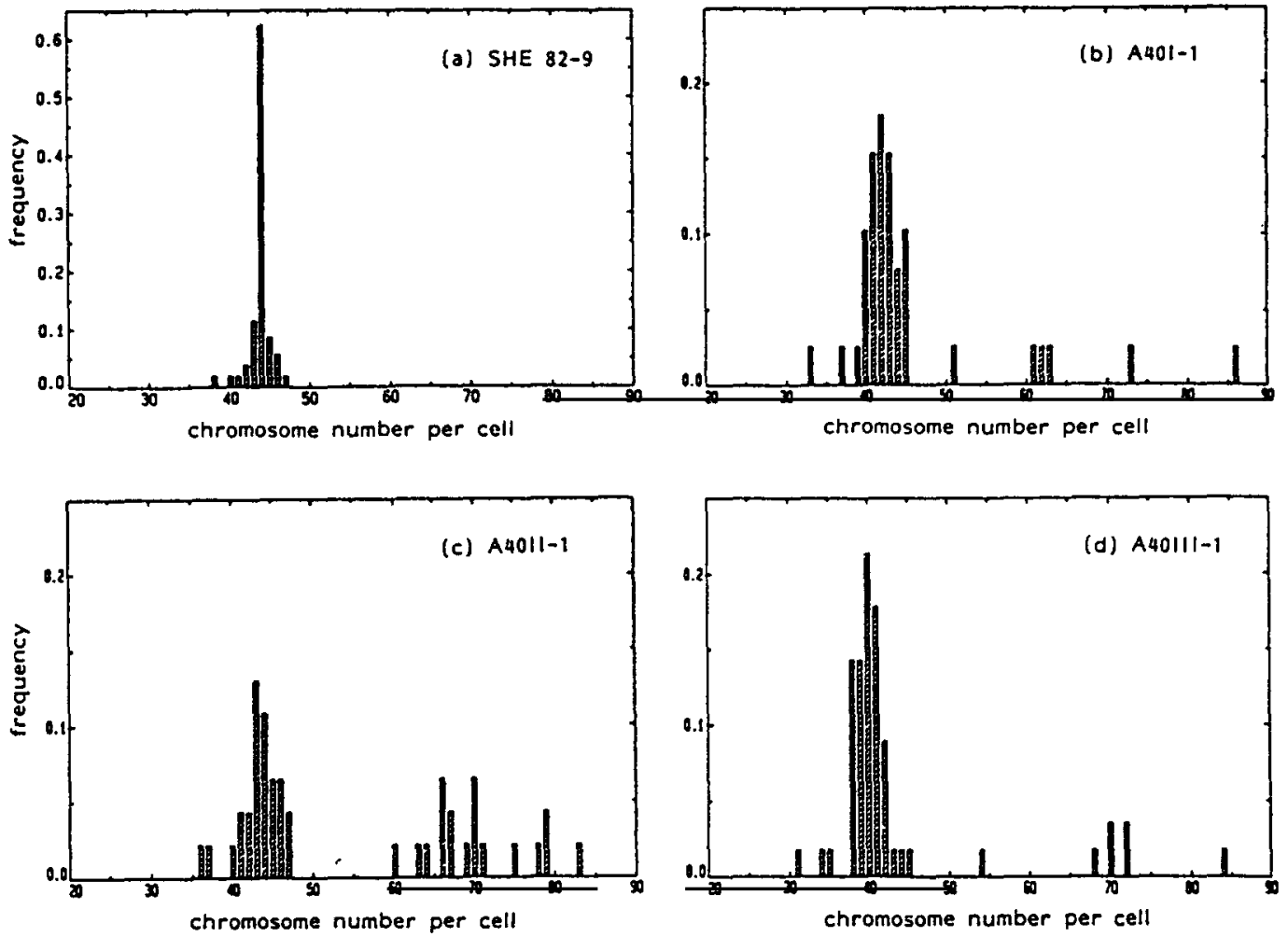

Fig. 2. Histograms of the chromosome number per cell of primary SFE cells or cells transformed by various fluences, $\Phi$, of $8 \mathrm{MeV} / \mathrm{u}$ carbon lons: (a) primary SHE cells; (b) $A 40 I-1, \Phi=5 \times 105 / \mathrm{cm}^{2}$; (c) $A 40 I I-1, \Phi=2 \times 10^{6} / \mathrm{cm}^{2}$; (d) $A 40 I I I-1, \Phi=4 \times 10^{6} / \mathrm{cm}^{2}$.
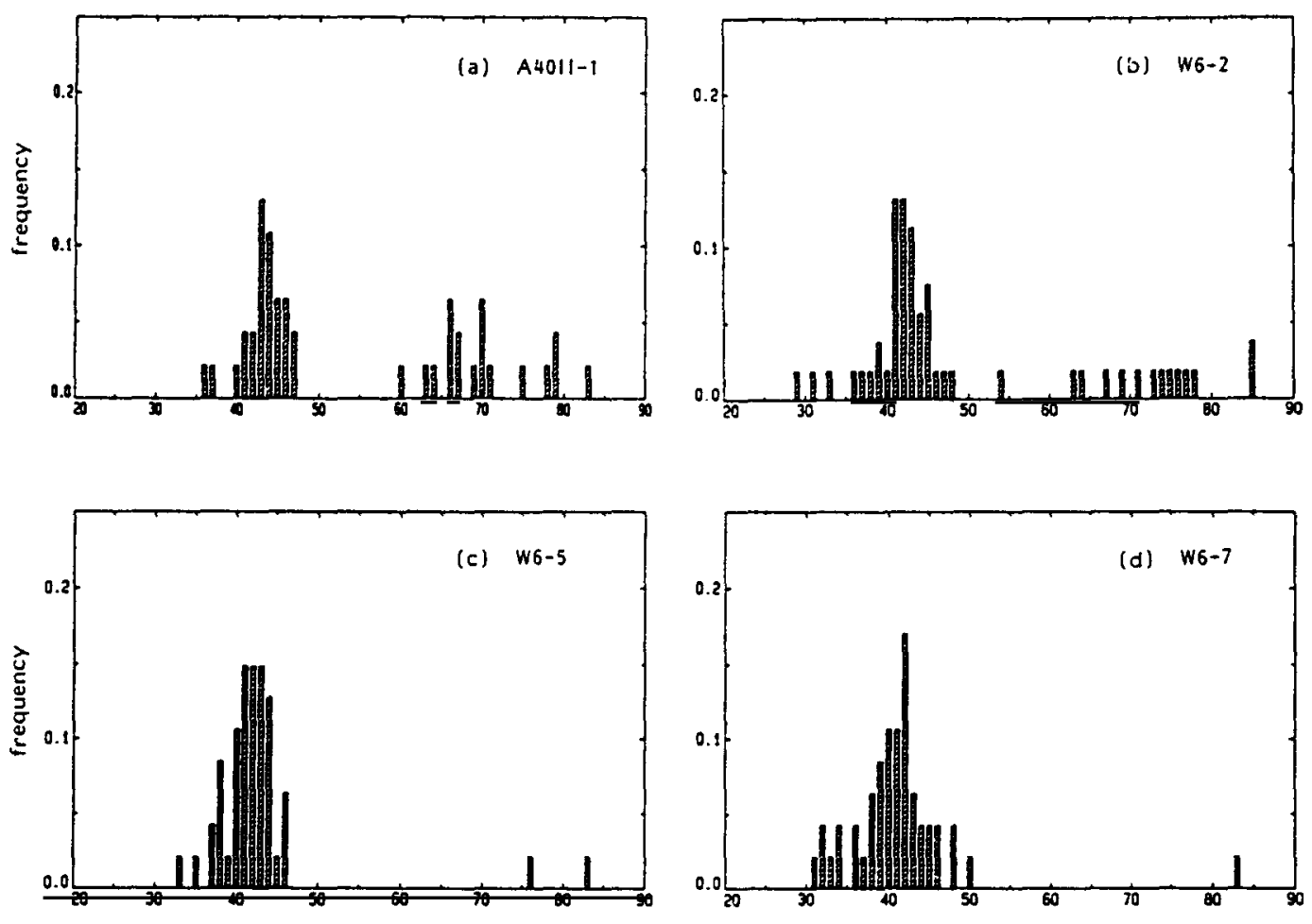

chromosome number per cell

chromosome number per cell

Fig. 3. Histograms of the chromosome number per cell of A40II-1 (a) and three subclones of A40II-1 cloned in soft agar $(b, c, d)$. 
The transformed cell lines exhibit, as shown in figure 2 b,c,d, somewhat varylng distributions of chromosome numbers. A4OIII-1 cells had a relatively narrow distribution of chromosome numbers around a median value close to only 40 , the other two cell lines had distributions slightly shifted to median numbers of 42 (A40I-1) and 46 (A40II-1) chromosomes per cell. All three cell lines contain varlous fractions of uneuploid cells with chromosome numbers up to 85 .

The soft-agar subclones of A40II-1 (figure $3 \mathrm{~b}, \mathrm{c}, \mathrm{d}$ ) had sinilar chromosome distributions as the parent cell line. The main components of their distributions have a similar width as that of A4OII-1. The fraction of uneuploid cells was smaller in two of the three subclones (figure $3 c, d$ ).

The tunor-cell Ine r2800 obtained from A40II-1 cells showed a sinilar distribution as the A40II-1 cells themselves (see figure $3 a$ and figure 4a); there was merely a slight shift towards the median of 40 chromosomes as the transformed cell line A40III-1. The soft agar subclones of $T 2800$ had a somewhat broader distribution, but the modian rematned at 40 to 41 chromosomes and there was only a small fraction of uneuplold cells with numbers in excess of 60 chromosomes.

It appears from these data that transformed cells and the resultant tumor cells need not be highiy uneuploid, 1.e. chromosome numbers higher than 50. On the contrary, it appears that the diploid or near diplold cells are most competent to grow in semi-solid mediun. One of the main feature of transformed cells is, thus, more clearly expressed in nearly euploid then in highly uneuploid cells.
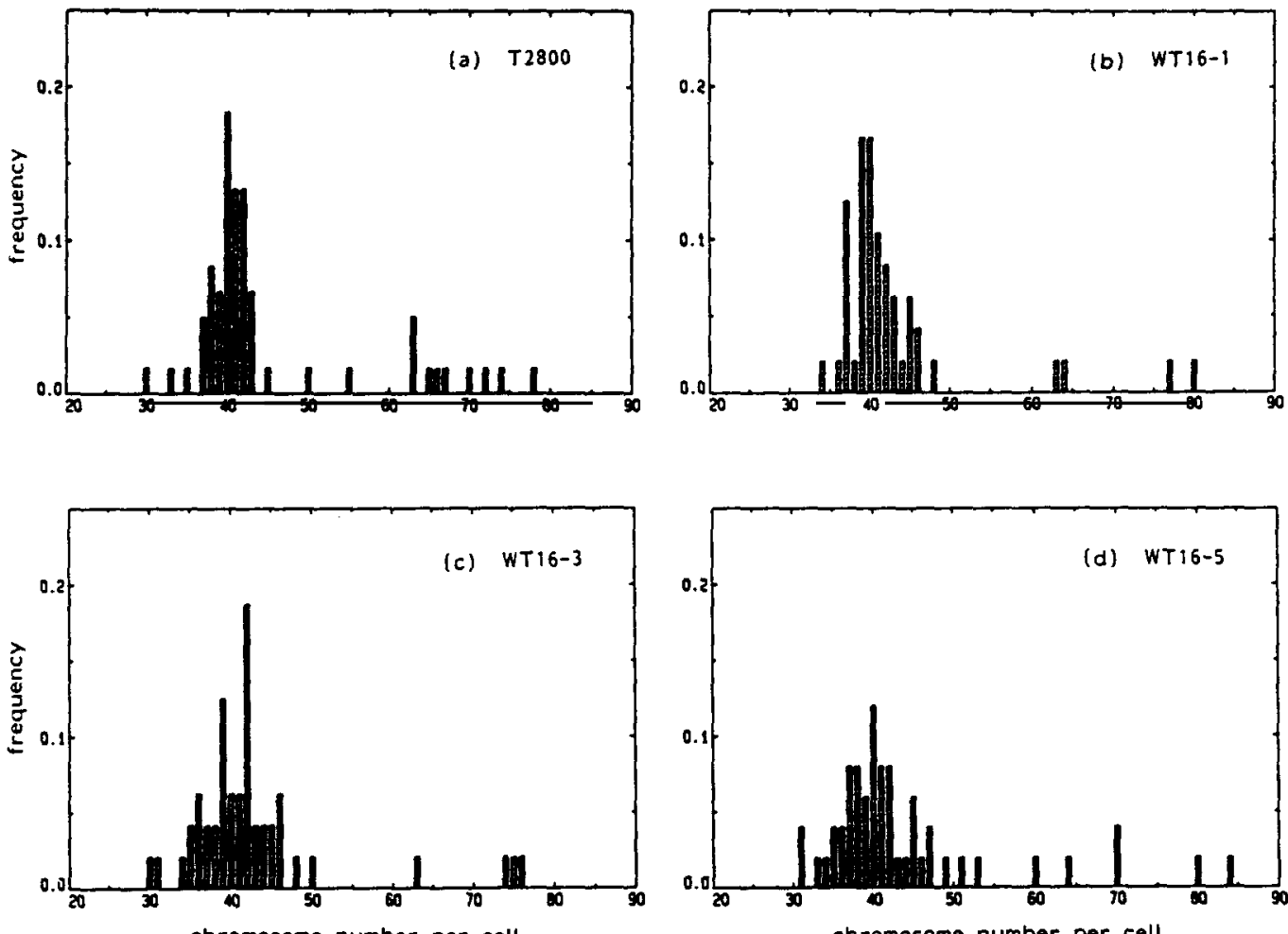

Fig. 4. Hetograms of the tumor-cell Iine T2800 (a) dertived from the transformed cell Iine A4OII-1 (fif. 2b) and three soft-agar subciones of T2800 (b,c,d).

Expresstion of $\mathrm{F}$-ras oncogene in cells transformed by carbon lons and in the resulting tunorcell lines

Expression of H-ras gene on the RNA-level has been determined by Northern blotting. For the hybridization 20 H5 total RNA of each cell line was seperated by electrophoresis on $1 \%$ agarose gels, blotted on Nylon filters, and hybrldized with a nick-translated human Ifras probe. Figure 5 shows an autoradiogram of a hybridization experiment with three carbon-ion transformed cell lines an the corresponding tumor-cell lines compared with prinary Syrian hanster cells $(82-9)$. 


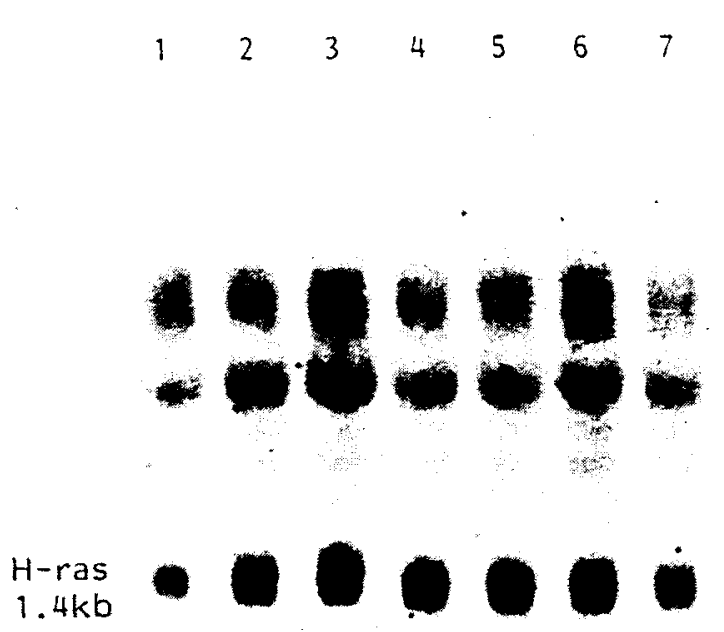

Fig. 5. Northern blot analysis of the expression of the fras oncogene for the three transformed cell lines A4OI-1 (lane 2), A4OII-1 (lane 4), and A40III-1 (lane 6) and the resulting tumor-cell Iines T2802 (lane 3), T2800 (lane 5), and T2799 (lane 7), compared to primary SHE cells (lane 1).

From this experiments it seems that the expression of the H-ras gene is enhanced in all transformed and all tumor-cell Ines. The enhancement of the F-ras expression has been determined quantitatively by densitometric scanning of the autoradiograms. For a better quantification the signals of the fras experiments were compared with signals of hybridization experiments with an actin probe, which did not change by the transformation event. The enhancement factors of the H-ras gene expression were betweenn 1.4 to 2.4. There were no clear differences between the transformed cell lines and the tumor-cell lines. Sinilar results have been found in cells transformed by cobelt- $\gamma$-rays and in a resulting tunor-cell ine. Experdments are now underway to investigate possible mutations or rearrangements of the ras gene including the promotor sequences. In addition, the expression of other oncogenes has to be investigated.

\section{ACKNOWL EDGEMTINS}

This work was supported by the Deutsche Forschungsgemeinschaft (DFG), Sonderforschungsbereich 172, $\mathrm{C}-1$ and by the Gesellschaft fir Schwerlonenforschuns (GSI), Darmstadt.

\section{REFERENCES}

1. C. Borek and E.J. Hall. Transformation of mamnalian cells in vitro by low doses of $x-$ rays, Nature 243, 450-453 (1973)

2. M. Terzeghi and J.B. Little, X-radiation-induced trensformation in a C3H mouse embryoderived cell Itre, Cancer Research, 36, 1367-1374 (1976)

3. R.C. Miller, E.J. Hall, and H.H. Ross1, Oncogenic transformation of mamalian cells in vitro with split doses of X-rays, PNAS, USA, 76, 5755-5758 (1979)

4. A. Han, C.K. Hill, and M.M. Elkind, Neoplastic transformation of 10M1/2 cells by $60-$ Co $\gamma$-rays: Evidence of repair of danage at reduced dose rate, Int. J. Radiat. Biol., 37. $585-589$ (1980)

5. R.C. Miller and E.J. Hall, X-ray dose fractionation and oncogenic transformation in cultured mouse embryo cells. Nature. 272, 58-60 (1978)

6. C. Borek, E.J. Hall, and H.H. Ross1, Malignant transformation in cultured hamster embryo cells produced by $X$ rays, $430 \mathrm{keV}$ monoenergetic neutrons, and heavy lons, fencer Research. 38, 2997-3005 (1978)

7. G.W. Barendsen, and J.F. Gatser, Cell transformation in vitro by fast neutrons of different energies: Implications for mechanisms. Radiat. Protect. Dos., 13, 145-148 (1985) 
8. A. Han and M.M. Wieind, Transformation of mouse C3H $10 \mathrm{M} / 2$ cells by single and fractionated doses of $x$-rays and fission spectrum neutrons, Cancer Research, 39, 123-130 (1979)

9. C.K. Hill, B.A. Carnes, A. Han, and M.K Micind, Neoplastic transformation is enhanced by multiple low doses of fission-spectrum neutrons, Radiation Research, 102, 404-410 (1985)

10. E.K. Balcer-Kublczek, G.E. Harrison, G.H. Zeman, P.J. Mattson, and A. Kunska, Lacik of inverse dose-rate effect on fission neutron-Induced transformation of C3H $10 T 1 / 2$ cells, Int. J. Radiat. Blol. in press (1988)

11. J.B. Robertson. A. Koehler. J. George, and J.B. Ifttle, Oncogente transformation of mouse Balb/3T3 cells by plutonium-238 a-particles, Radiation Research, 96, 261-274 (1983)

12. E. L. Iloyd, M.A. Gemmell, C. B. Henning, D.S. Cemmell, and B.J. Zabransky, Transformation of mamalian cells by a-particles, Int. J. Radiat. Biol. 36, 467-478 (1979)

13. E.J. Hall and T.K. Hel, Oncogentc transformation in vitro by radiation of varying IDT, Padiat. Protect. Dos., 13, 149-151 (1985)

14. I. Hieber, G. Ponsel, H. Roos, S. Fenn, E. Fronke, and A.M. Rellerer, Absence of a doserate effect in the transformation of C3H $10 \mathrm{M} / 2$ cells by $\alpha$-particles, Int. I Radiat. Biol., 52, 859-869 (1987)

15. T. Yans, I. Craise, M. Me1, and C. Tobias, C. Neoplastic cell transformation by heavy charged particles, Radiation Research, 1045, 177-187 (1985)

16. C. Reznlkoff, J. Bertram, D.W. Brankow, and C. Heidelberger, Quantitative and qualitative studies of chemical transformation of clonal C3H mouse embryo cells sensitive to post-confluence inhibition of cell division, Cancer Research. 33, 3239-3249 (1973)

17. G. Kraft, H.W. Daues, B. Fischer, U. Zopf, H.P. Ifiebold, D. Quis, H. Stelzer, J. Kiefer F. Schöpfer, E. Schneider, K. Weber, H. Whlf, and H. Dertinger, H. Irradiation chamber and sample changer for blologlcal samples, Nuclear Instruments and Methods, 168, 175-179 (1980)

18. W.I. Schaeffer and K. Friend, Efficient detection of soft agar grown colonies using a tetrazolium salt, Cancer Ietters. 1, 259-262 (1976)

19. P. Chomczynskt, and N. Sacchi, Single-step method of RNA 1solation by acid guantdintum thiocyanato-phenol-chloroform extraction, Analytical Blochemistry. 162, 156-159 (1987)

20. H. Wulf, W. Kraft-Weyrather, H. G. Miltenburger, E.A. Blakely, C.A. Toblas, and G. Kraft, Heavy-ion effects on mamalian cells: Inactivation measurements with different cell IInes, Radiation Research, 1045, 122-134 (1985)

21. ICRU Report 40, The quality factor in radiation protection, International Comision on Radiation Units and Measurements, Bethesda, Md. (1986) 